\begin{tabular}{|c|c|c|}
\hline & JHE 5 (2) (2020) 72-77 & 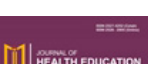 \\
\hline & Journal of Health Education & \\
\hline $\begin{array}{l}\text { Journal of } \\
\text { HealthEducation }\end{array}$ & http://journal.unnes.ac.id/sju/index.php/jhealthedu & $=$ \\
\hline
\end{tabular}

\title{
Quality of Comprehensive Midwifery Care as A Determinants of The Quality of Life of A Postpartum Mother
}

\author{
Dewi Susilawati ${ }^{\varpi}$, Nur Fadjri Nilekesuma \\ DOI: http://dx.doi.org/10.15294/jhe.v5i2.40218
}

STIKes Mercubaktijaya, Indonesia

\section{History Article \\ Submitted 15 July 2020 \\ Revised 22 August 2020 \\ Accepted 27 September 2020}

\section{Keywords}

patient satisfaction; quality of life of postpartum mothe; quality of midwifery care

\begin{abstract}
Background: One of the strategic efforts to reduce maternal mortality rate (MMR) is through the provision of comprehensive midwifery care. from pregnancy, childbirth to the puerperium. Indicators of success in midwifery care can be seen from the quality of life of postpartum mothers. Preliminary studies in Agam and Pasaman districts show that $50 \%$ of post-partum mothers have a poor quality of life. Method: This analytic descriptive study with a cross-sectional design involved postpartum mother as the subject. The sample of the study was many postpartum mothers who received midwifery services at practicing independent midwives in Pasaman and Agam districts. Samples were taken using the accidental sampling technique within 1 month. A questionnaire for evaluating the quality of life of postpartum women is used as an instrument to measure the quality of life of postpartum mothers. Data were analyzed univariate and bivariate using the chi-square test Results: A total of $75.4 \%$ of the research subjects had a good quality of life. There is a relationship between service quality $(p=0.001)$ and maternal satisfaction $(p=$ 0.001 ) with the quality of life for postpartum mothers.

Conclusion: The better the quality of midwifery services and the level of satisfaction with services, the better the quality of life for postpartum mothers. Therefore, it is recommended that midwives maintain the quality of midwifery care starting from pregnancy, childbirth to childbirth on an ongoing basis (continuity of care).
\end{abstract}

\section{How to Cite}

Susilawati, D., \& Nilekesuma, N. F. (2020). Quality of Comprehensive Midwifery Care as A Determinants of The Quality of Life of A Postpartum Mother. JHE (Journal of Health Education), 5(2), 72-77.

\footnotetext{
${ }^{\square}$ Corresponding Author:
}

Jl. Jamal Jamil Pondok Kopi Siteba, Surau Gadang, Nanggalo, Padang

E-mail: dewisusilawati39@gmail.com 


\section{INTRODUCTION}

Maternal Mortality Rate (MMR) is an indicator that can describe the welfare of the people in a country. The results of the Indonesian Demographic and Health Survey (IDHS) in 2017 showed the MMR of 305/100,000 live births and the Infant Mortality Rate (IMR) at 24/100,000 live births. Meanwhile, one of the provinces with a fairly high MMR is West Sumatra, reaching 107/100,000 live births (Kemenkes RI, 2018).

Two districts in West Sumatra that have a fairly high MMR are Agam and Pasaman districts. The number of MMR in Agam district in 2018 was recorded as many as 12 cases, of which 6 cases occurred during the postpartum (Tim Penyusun Data Perspektif Gender Kabupaten Agam, 2019). Meanwhile, in Pasaman district, the maternal mortality rate was recorded as many as 7 cases, of which 2 cases occurred during the postpartum and 5 during childbirth (Tim Penyusun Buku Data Profil Gender Kabupaten Pasaman, 2019).

The MMR data on the high MMR during the postpartum period in Pasaman and Agam districts indicated that the quality of midwifery care was not optimal. The MMR profile in the two districts is due to the fact that many midwives have not provided optimal care to mothers during pregnancy, childbirth, and postpartum (Rochmayani, 2018).

One of the government's strategies in reducing MMR is to ensure that every mother gets continuity of care starting from pregnancy, childbirth to postpartum so that it has a big impact on the health of mothers and children (Kemenkes RI, 2018). The success of the care provided on an ongoing basis (continuity of care) can be seen by improving the quality of life for postpartum mothers.

Based on a preliminary study conducted on 10-18 August 2019 in postpartum mothers who received care from the Independent Practice Midwives (BPM) in Agam Regency, it was found that $66.7 \%$ of postpartum mothers had a poor quality of life. Meanwhile, in Pasaman district as much as $60 \%$ of postpartum mothers have a poor quality of life.

The quality of life for postpartum mothers is influenced by problems related to pregnancy, childbirth, and the postpartum. Complications and discomfort that arise in postpartum women due to the process of pregnancy, childbirth, and postpartum have a negative impact on the quality of life of the mother (Miguel, et al., 2019).
Previous research has examined the factors that influence the quality of life for postpartum mothers. Some of the factors that affect the quality of life of postpartum mothers include education, maternal activities, social support, economic status, type of labor, parity, ability to self-care during the postpartum period, and care during antenatal care (Chinweuba et al., 2018; Ghiasvand, et al., 2017; Hitimana et al., 2018; Miguel, et al., 2019; Özdemir, et al., 2018; Tomasoa, 2017). Other studies have shown that mothers who receive antenatal care at least 4 times during pregnancy can reduce complications or discomfort during labor and childbirth (Özdemir et al., 2018).

The above studies generally show the role of the mother's internal factors as a determinant of the quality of life of the postpartum mother. To complete the understanding of the determinants of the quality of life for postpartum mothers, it is also necessary to study the quality of midwifery care received by mothers during pregnancy, childbirth, and the postpartum sustainably and comprehensively. Therefore, it is necessary to study the relationship between the variable quality of midwifery care and the satisfaction of postpartum mothers with midwifery care and the quality of life for postpartum mothers.

\section{METHODS}

\section{Research Design and Sample}

This type of research is descriptive analytic with a cross-sectional design. The sample in this study was postpartum mothers who were given midwifery care starting from pregnancy to childbirth by midwives at Independent Practice Midwives (BPM) in the Pasaman and Agam districts. The reason for choosing the sample from BPM in Agam and Pasaman districts is because the highest percentage of mothers giving birth is in the Independent Practice Midwives (BPM).

The minimum sample size required in this study is 56 postpartum mothers. The sampling technique used accidental sampling in a period of 1 month, from 1 July to 31 July 2020. The number of subjects available during that time period was 69 postpartum mothers. In this research, all available subjects were used as research samples, namely 69 postpartum mothers. The sample selection inclusion criteria in this study were postpartum mothers who received care from pregnancy to childbirth. The exclusion criteria used were postpartum mothers who did not receive comprehensive care and postpartum mothers who were not willing to be the samples. 


\section{Research Procedure}

Researchers' data collection was assisted by 30 enumerators which each research location there was 1 enumerator. Before doing the research, the researcher did a perception equation with the enumerator. The questionnaire filled out by the sample is already in the form of a google form so that every time the questionnaire is filled in, the results are immediately obtained by the researcher.

\section{Variables, Data Collection Techniques, and Research Analysis}

The independent variables of this study were the quality of midwifery care and the satisfaction of postpartum mothers with the care received from the midwives. The dependent variable of this study is the quality of life of the postpartum mother.

Data collection on service quality and satisfaction variables used questionnaires that had been tested for validity and reliability where the result was that all of the questionnaires used were valid because $r$ count was greater than $r$ table $(0.244)$ and all questionnaires were also reliable because the Cronbach alpha value was more than 0.6 where the results are the variable service quality 0.936 and the satisfaction variable 0.889 . The variable of the quality of life of postpartum women was measured using an instrument developed in Zubaran (2019) research, namely the questionnaire for evaluating the quality of life of postpartum mothers developed (Zubaran, et al., 2019).

Data processing by editing, coding, entry, tabulating, and cleaning. Data analysis includes univariate and bivariate analysis. The non-parametric chi-square test was used to analyze the relationship between the variable quality of service and service satisfaction with the variables of the quality of life of the postpartum mother.

\section{RESULTS AND DISCUSSIONS}

Table 1 presents the frequency distribution of the variable quality of midwifery care, satisfaction of postpartum mothers with the care received, and the quality of life of the postpartum mothers.

\section{Quality of Midwifery Care}

Based on the results of the study, it was found that most of the samples stated that the quality of care provided by midwives during pregnancy to childbirth was categorized as good. The quality of midwifery care provided from pregnancy, labor to childbirth is categorized as good if the care provided are under the quality standards of midwifery care including caring, collaboration, speed, empathy, courtesy, sincerity, and therapeutic communication (Miguel, et al., 2019).

Table 1. Distribution of Comprehensive Quality of Midwife Service Quality in BPM Pasaman and Agam Districts $(\mathrm{n}=69)$

\begin{tabular}{lll}
\hline Variable & Frequency & Percentage \\
\hline Midwifery Care & & \\
Quality & 40 & 58 \\
Good & 17 & 24.6 \\
Good enough & 12 & 17.4 \\
Poor & & \\
Satisfaction & & \\
High & 41 & 59.4 \\
Moderate & 24 & 34.8 \\
Low & 4 & 5.8 \\
Quality of Life of the & & \\
Postpartum Mother & & \\
Good & 52 & 75.4 \\
Poor & 17 & 24.6 \\
\hline
\end{tabular}

The results of this study are in line with research conducted by Woworo (2019), namely the quality of care received by a sample of more than half is categorized as good. In this study, are quality was assessed by taking into account the aspects of physical evidence, reliability, responsiveness, assurance, and empathy (Woworo, et al., 2019).

Another study conducted by Taekab (2019) also shows similar results. In this study, it was reported that most of the quality of care received by the sample was categorized as good (Taekab, et al., 2019).

Quality of care is said to be of quality if it is under the expectations or needs of care recipients. To be able to find out whether the quality of the care provided is under the desires of the care recipients, the care quality must also be measured and assessed from the care recipients. This is relevant to the results of research by Kurniati (2020) which states that "care quality is successfully built if the care provided get recognition from care recipients" (Kurniati, 2020).

\section{Postpartum Satisfaction with Midwifery Care}

The results showed that most of the samples expressed satisfaction with the care obtained during pregnancy to childbirth, mostly in the good category. Postpartum mother satisfaction with midwifery care is the perception of satisfac- 
tion of postpartum mothers with the quality of midwifery care provided from pregnancy, childbirth to postpartum (Esthi, et al., 2017).

The results of this study are basically in line with the results of research conducted by Woworo (2019), where the results are more than $50 \%$ of the sample expressed satisfaction with the care received (Woworo et al., 2019). The results of this study are also in line with research conducted by other researchers, where more than half of the sample were satisfied with the care provided (Harun \& Wijayantono, 2019).

Patient satisfaction is assessed based on sample interpretations regarding the suitability of expectations and what is received including the speed/urgency of officers in providing assistance and friendliness of officers in providing care (Yun, et al., 2017).

The satisfaction of postpartum mothers is influenced by the care provided by health workers, whether provided by doctors, midwives, or administrative staff, as well as existing infrastructure (Yun et al., 2017). With the same care for the same case, the level of satisfaction that the patient feels will vary. This depends on the patient's own background, individual characteristics that have existed before the onset of the disease, which is called predisposing factors. These factors include rank, economic level, social position, education, socio-cultural background, general ethnicity, gender, mental attitude, and personality.

One of the efforts to increase the satisfaction of postpartum mothers with the care they receive is by increasing the quality of care, namely providing sustainable care. This is intended to improve care quality. Therefore, midwives must provide more pregnancy, childbirth, and postpartum care, provide information according to client needs, provide continuous care, carry out client-centered communication, approach clients personally, and give clients sufficient time (Baas, et al., 2015).

\section{The Quality of Life of the Postpartum Mothers}

Based on the research results, it was found that almost all samples had a quality of life in the good category. The quality of life of the postpartum mother is a description of the health of the postpartum mothers and her ability to carry out her duties as a mother. The quality of life of postpartum mothers was measured by filling out a questionnaire for evaluating the quality of life of postpartum women (Esthi et al., 2017; Zubaran et al., 2019).

The results of this study are in line with research conducted by Miguel (2019) which the quality of life is influenced by problems related to pregnancy, childbirth, and postpartum. In this study, the discomfort that arises in postpartum mothers due to the process of pregnancy, childbirth, and postpartum has a negative impact on the quality of life of the mother (Miguel, et al., 2019).

In this study, it was found that mothers with poor quality of life were influenced by maternal parity and maternal education. Another study conducted by Windarti (2018) states that primiparous mothers are mostly less able to care for themselves. Primi's mother has no experience in taking care of herself and her baby, so she tends to learn and try harder to adjust to the conditions she is experiencing (Windarti \& Dewi, 2018). At this time, the mother needs family assistance/family support, if the mother is unable to get through this period, the mother will likely experience depression automatically if the mother is depressed or cannot take care of herself, then the mother's quality of life will be poor.

Family support is one that affects the quality of life for postpartum mothers. According to José Matías Triviño-Juárez (2016), the presence of a partner not only during pregnancy and childbirth but also during the postpartum will strengthen the relationship between the couple and their child, thereby increasing the mother's confidence in breastfeeding. Mothers who provide breast milk for at least 6 months can improve the quality of life of postpartum mothers. However, the positive effect on the quality of life of the mother may be due to factors supporting the mother's breastfeeding instead of breastfeeding itself, such as support from the family of the spouse (TriviñoJuárez et al., 2016).

Research related to postpartum visits by midwives to postpartum mothers shows that most samples with higher education received care from midwives. The opposite situation occurs in samples with low and secondary education. Visits after giving birth are rarely carried out due to several reasons such as lack of knowledge and experience and lack of information obtained (Pradani \& Kurniasari, 2018). Research shows that home visits by midwives to postpartum maternal patients significantly improve the quality of life for postpartum mothers (Tomasoa, 2017).

The summary of the results of the analysis of the relationship between the quality of midwifery care and satisfaction of care given on the quality of life of postpartum mothers can be seen in Table 2. 
Table 2. Relationship between the quality of comprehensive midwifery care and the quality of life of postpartum mothers in BPM, Pasaman, and Agam Regencies

\begin{tabular}{|c|c|c|c|c|c|c|c|}
\hline \multirow{3}{*}{ Variable } & \multicolumn{4}{|c|}{ Quality of Life } & \multirow{2}{*}{\multicolumn{2}{|c|}{ Total }} & \multirow{3}{*}{$\begin{array}{c}\mathrm{p}- \\
\text { value }\end{array}$} \\
\hline & \multicolumn{2}{|c|}{ Good } & \multicolumn{2}{|c|}{ Poor } & & & \\
\hline & $\mathrm{f}$ & $\%$ & $\mathrm{f}$ & $\%$ & $\mathrm{f}$ & $\%$ & \\
\hline \multicolumn{8}{|c|}{ Midwifery Care Quality } \\
\hline Good & 37 & 92.5 & 3 & 7.5 & 40 & 100 & 0.001 \\
\hline Good enough & 8 & 47.1 & 9 & 52.9 & 17 & 100 & \\
\hline Poor & 7 & 58.3 & 5 & 41.7 & 12 & 100 & \\
\hline Total & 52 & 75.4 & 17 & 24.6 & 69 & 100 & \\
\hline \multicolumn{8}{|l|}{ Satisfaction } \\
\hline High & 38 & 92.7 & 3 & 7.3 & 41 & 100 & 0.001 \\
\hline Moderate & 14 & 58.3 & 10 & 41.7 & 24 & 100 & \\
\hline Low & 0 & 0 & 4 & 100 & 4 & 100 & \\
\hline Total & 52 & 75.4 & 17 & 24.6 & 69 & 100 & \\
\hline
\end{tabular}

The Relationship Between the Quality of Midwifery Care and the Quality of Life of Postpartum Mothers

Table 2 shows that most of the postpartum mothers who receive quality care have a good quality of life. This result is in line with Aminah's 2017 research which states that there is a significant relationship between the quality of care provided and the quality of care received (Aminah, 2017).

Several studies have revealed that patients who receive professional health care are often from patients with a high level of education. This is possible because patients with high education tend to easily accept the information provided. Even though the quality of care provided by health workers is actually lacking, patients with high education will try to get health information from other media so that the quality of life of these mothers will be better.

The quality of life of postpartum mothers is not only influenced by one's education but also by the activities of the postpartum mothers. Postpartum mothers with good educational background and active work outside the home are psychologically more interested in finding information about health care independently (Rahayuningsih, 2017).

Miguel (2019) in his study also confirmed a significant relationship between the quality of midwifery care and the quality of life for postpartum mothers. The study revealed that optimal quality of care can help patients overcome the discomfort that occurs in postpartum mothers due to pregnancy, childbirth, and postpartum processes that have a negative impact on the quality of life of these mothers (Miguel, et al., 2019). One of the steps in providing midwifery care to reduce maternal discomfort is to provide counseling to mothers starting from pregnancy to the postpartum period. Postpartum mothers who receive health psycho-education actually have lower levels of anxiety and better levels of emotional well-being (Fenwick et al., 2015).

\section{Relationship between Satisfaction of Mid- wifery Care and Quality of Life of Postpartum Mother}

The data in table 2 shows a significant relationship between satisfaction with midwifery care and the quality of life for postpartum mothers. The results of this study are in line with the findings of previous studies. Esthi's research (2017) confirms that the better the quality of care, the higher the level of patient satisfaction (Esthi et al., 2017). The findings of this study strengthen the understanding of the importance of quality midwifery care so that patient satisfaction with care is better (Andriani, 2017).

\section{CONCLUSION}

Based on the results of the study, it can be concluded that the quality of midwifery care and satisfaction with midwifery care are determinants of the quality of life for postpartum mothers. Based on the conclusions of the study, it is recommended that midwives always maintain their professional commitment, so that they can provide sustainable and comprehensive midwifery care from pregnancy, childbirth to the postpartum. 


\section{REFERENCES}

Aminah. (2017). Hubungan pelaksanaan program dan kebijakan teknis pelayanan oleh bidan desa dengan kepuasan ibu nifas di wilayah kerja puskesmas tanah jawa. Jurnal Ilmiah Kebidanan Imelda, 3(1), 233-239.

Andriani, A. (2017). Hubungan Mutu Pelayanan Kesehatan Dengan Kepuasan Pasien Diruangan Poli Umum Puskesmas Bukittinggi. Jurnal En durance, 2(1), 45-52.

Baas, C. I., Erwich, J. J. H. M., Wiegers, T. A., de Cock, T. P., \& Hutton, E. K. (2015). Women's Suggestions for Improving Midwifery Care in The Netherlands. Birth, 42(4), 369-378.

Chinweuba, A. U., Okoronkwo, I. L., Anarado, A. N., Agbapuonwu, N. E., Ogbonnaya, N. P., \& Ihudiebube-Splendor, C. N. (2018). Differentials in health-related quality of life of employed and unemployed women with normal vaginal delivery. BMC Women's Health, 18(1), 1-10.

Esthi, F. S., Mindarsih, E., \& Murni, M. (2017). FaktorFaktor Mutu Pelayanan Kebidanan yang Mempengaruhi Tingkat Kepuasan Pasien di Poli Kebidanan RSUD Wonosari. Jurnal Kesehatan Ibu Dan Anak, 11(2), 35-42.

Fenwick, J., Toohill, J., Gamble, J., Creedy, D. K., Buist, A., Turkstra, E., ... Ryding, E. L. (2015). Effects of a midwife psycho-education intervention to reduce childbirth fear on women's birth outcomes and postpartum psychological wellbeing. BMC Pregnancy and Childbirth, 15(1), 1-8.

Ghiasvand, F., Riazi, Hedyeh, Hajian, Sepideh, Kazemi, E., \& Firoozi, A. (2017). The Effect of a Self-Care Program Based on the Teach Back Method on the Postpartum Quality of Life. Electronic Physician, 9(4), 4180-4189.

Harun, H., \& Wijayantono. (2019). Analisis Faktor Yang Mempengaruhi Mutu Pelayanan Kesehatan Terhadap Kepuasan Pasien Di Puskesmas Rawat Inap Kabupaten Pasaman 2019. Human Care Journal, 4(3), 138.

Hitimana, R., Lindholm, L., Krantz, G., Nzayirambaho, M., Condo, J., Sengoma, J. P. S., \& Pulkki-Brännström, A. M. (2018). Health-related quality of life determinants among Rwandan women after delivery: Does antenatal care utilization matter? A cross-sectional study. Journal of Health, Population and Nutrition, 37(1), 1-10.

Kemenkes RI. (2018). Data Dan Informasi Profil Kesehtan Indonesia 2017.

Kurniati, C. H. (2020). Hubungan antara kualitas bidan dalam pelayanan antenatal care terhadap persepsi ibu hamil. Jurnal Ilmiah Rekam Medis Dan Informatika Kesehatan, 10(1), 36-40.

Miguel, J., Hern, A., Delgado-rodr, M., \& Rubioalvarez, A. (2019). Women's Quality of Life at 6 Weeks Postpartum: Influence of the Discomfort Present in the Puerperium. 16(253), 1-9.

Miguel, J., Hernandez, A., Rodriguez, J., \& Degado, M. (2019). Quality of Life of Women after Giv- ing Birth: Associated Factors Related with the Birth Process. Clinical Medicine, 8(324). https:// doi.org/10.3390/jcm8030324

Özdemir, F., Öztürk, A., Karabulutlu, Ö., \& Tezel, A. (2018). Determination of the life quality and self-care ability of the mothers in post-partum period. Journal of the Pakistan Medical Association, 68(2), 210-215.

Pradani, N. N. W., \& Kurniasari, C. V. (2018). Hubungan Paritas, Umur dan Pendidikan dengan Kunjungan Nifas. Oksitosin, Kebidanan, 5(2), 67-78.

Rahayuningsih, F. B. (2017). Hubungan antara dukungan sosial dengan kualitas hidup ibu nifas di Kecamatan Miri Kabupaten Sragen. Prosisding Seminar Ilmiah Nasional Kesehatan, 125-129.

Rochmayani. (2018). Actors contributing in the decline of maternal mortality and labor services problems. Jurnal Kesehatan Masyarakat, 4(1), 43-47.

Taekab, A. H., Suryawati, C., \& Kusumastuti, W. (2019). Analisis Persepsi Pasien Terhadap Mutu Pelayanan Puskesmas Dan Hubungannya Dengan Kepuasan Pasien Rawat Jalan Di Puskesmas Leyangan Kabupaten Semarang Tahun 2018. Jurnal Kesehatan Masyarakat, 7(1), 31-40.

Tim Penyusun Buku Data Profil Gender Kabupaten Pasaman. (2019). Data Perspektif Gender Kabupaten Pasaman Tahun 2019.

Tim Penyusun Data Perspektif Gender Kabupaten Agam. (2019). Buku Data Perspektif Gender Kabupaten Agam Tahun 2018.

Tomasoa, Z. Z. (2017). Hubungan antara jumlah kunjungan nifas dengan kualitas hidup ibu nifas di Puskesmas Sewon i Bantul. Sekolah Tinggi Kesehatan Jendral Achmad Yani.

Triviño-Juárez, J. M., Nieto-Pereda, B., Romero-Ayuso, D., Arruti-Sevilla, B., Avilés-Gámez, B., Forjaz, M. J., ... Plá-Mestre, R. (2016). Quality of life of mothers at the sixth week and sixth month post partum and type of infant feeding. Midwifery, 34, 230-238.

Windarti, Y., \& Dewi, U. M. (2018). Pengaruh Paritas Dan Media Konseling Masa Nifas Terhadap Kemampuan Perawatan Mandiri Ibu Post Partum Di Bpm Vivi Surabaya. Journal of Health Sciences, 11(1), 28-32.

Woworo, J., Adisti A. Rumayar, \& Franckie R.R. Maramis. (2019). Hubungan Antara Mutu Jasa Pelayanan Kesehatan Dengan Kepuasan Pasien Rawat Inap Di Rumah Sakit Cantia Tompaso Baru. Kesehatan Masyarakat, 8(6), 560-576.

Yun, D. C., Hakim, L., \& Sembiring, R. (2017). Faktorfaktor yang Mempengaruhi Pelayanan Kebidanan Terhadap Kepuasan Ibu Nifas di Rumah Sakit Islam Malahayati Medan Tahun 2017. Jurnal Ilmiah Kohesi, 1(3), 86-99.

Zubaran, C., Foresti, K., Schumacher, M. V., Muller, L. C., \& Amoretti, A. L. (2019). An assessment of maternal quality of life in the postpartum period in southern Brazil: A comparison of two questionnaires. Clinics, 64(8), 751-756. 